\title{
Responsivitas Pelayanan Publik Di Era Pemberlakuan Pembatasan Kegiatan Masyarakat (Ppkm) Pada Dinas Kependudukan Dan Catatan Sipil Kabupaten Bolaang Mongondow
}

\author{
Abdul Rahman Dilapanga ${ }^{\text {a, }}$ * \\ ${ }^{a}$ Universitas Negeri Manado, Prodi Ilmu Administrasi Negara, Manado, Indonesia \\ 1 abdulrahmandilapanga@unima.ac.id *
}

IN F O A R T IKEL

Key word:

Employee,

Disdukcapil,

Bolaang Mongondow

\section{A B S T R A C T}

This study aims to analyze and interpret the Responsiveness of Public Services in the Era of Restrictions on Community Activities at the Population and Civil Registry Office of Bolaang Mongondow Regency, using a qualitative descriptive research approach at the Department of Population and Civil Registry of Bolaang Mongondo Regency. The results found are that employees at the Population and Civil Registry Office of Bolaang Mongondow Regency respond to every community / applicant who wants to get service with excellence and totality and in accordance with existing procedures by implementing the Enforcement of Community Activity Restrictions (PPKM) with the attitude and communication provided by the community. Disdukcapil employees who can be said to be good so that people feel comfortable.

\section{INTISARI}

\section{Kata kunci:}

Pegawai,

Disdukcapil,

Bolaang Mongondow
Penelitian ini bertujuan untuk menganalisis dan menginterpretasikan Responsivitas Pelayanan Publik di Era Pemberlakuan Pembatasan Kegiatan Masyarakat Pada Dinas Kependudukan dan Catatan Sipil Kabupaten Bolaang Mongondow, dengan menggunakan pendekatan penelitian deskriptif kualitatif di Dinas Kependudukan dan Catatan Sipil Kabupaten Bolaang Mongondo. Hasil yang ditemukan adalah para Pegawai di Dinas Kependudukan Dan Catatan Sipil Kabupaten Bolaang Mongondow merespon setiap masyarakat / pemohon yang ingin mendapatkan pelayanan dengan prima dan totalitas dan sesuai dengan prosedur yang ada dengan menerapkan Pemberlakuan Pembatasan Kegiatan Masyarakat (PPKM) dengan sikap dan komunikasi yang diberikan oleh pegawai Disdukcapil yang dapat dikatakan baik sehingga masyarakat merasa nyaman.

Copyright (C) 2021 (Abdul Rahman Dilapanga). All Right Reserved

\section{Pendahuluan}

Pada hakekatnya pelayanan publik merupakan hak masyarakat yang oleh masyarakat diberikan mandat kepada negara untuk menyelenggarakannya, oleh karena itu negara dalam hal ini pemerintah berkewajiban memberikan pelayanan kepada setiap warga negara untuk memenuhi hak dan kebutuhan dasarnya dalam kerangka pelayanan publik. Hal ini menjadi bahan 
pertimbangan DPR-RI dalam pengesahan UU No: 25 Tahun 2009 tentang Pelayanan Publik, "bahwa negara berkewajiban melayani setiap warga negara dan penduduk untuk memenuhi hak dan kebutuhan dasarnya dalam kerangka pelayanan publik yang merupakan amanat Undang-Undang Dasar Negara Republik Indonesia Tahun 1945" [1].

Pelayanan publik berarti memberikan layanan barang ataupun jasa yang dibutuhkan masyarakat dalam segala bidang, baik yang dilakukan oleh individu, kelompok masyarakat, ataupun organisasi pemerintah maupun swasta untuk memberikan bantuan dan kemudahan bagi masyarakat sehingga kebutuhannya terpenuhi. Thoha mengemukakan "pelayanan masyarakat adalah usaha yang dilakukan oleh seseorang dan atau kelompok orang atau instansi tertentu untuk memberi bantuan dan kemudahan kepada masyarakat dalam mencapai tujuan" [2].

Dalam UU No: 25 Tahun 2009, pasal 1, ayat (1) dirumuskan bahwa: "Pelayanan publik adalah kegiatan atau rangkaian kegiatan dalam rangka pemenuhan kebutuhan pelayanan sesuai dengan peraturan perundang-undangan bagi setiap warga negara dan penduduk atas barang, jasa, dan/atau pelayanan administratif yang disediakan oleh penyelenggara pelayanan publik". Selanjutnya dalam ayat (2) disebutkan "Penyelenggara pelayanan publik yang selanjutnya disebut Penyelenggara adalah setiap institusi penyelenggara negara, korporasi, lembaga independen yang dibentuk berdasarkan undang-undang untuk kegiatan pelayanan publik, dan badan hukum lain yang dibentuk semata-mata untuk kegiatan pelayanan publik" [1].

Dinas Kependudukan dan Catatan Sipil Kabupaten Bolaang Mongondow adalah salah satu institusi negara atau organisasi perangkat daerah yang menyelenggarakan pelayanan publik. Dalam UU Nomor; 25 tahun 2009 pasal 1, ayat (4) dirumuskan; "Organisasi penyelenggara pelayanan publik yang selanjutnya disebut Organisasi Penyelenggara adalah satuan kerja penyelenggara pelayanan publik yang berada di lingkungan institusi penyelenggara negara, korporasi, lembaga independen yang dibentuk berdasarkan undangundang untuk kegiatan pelayanan publik, dan badan hukum lain yang dibentuk semata-mata untuk kegiatan pelayanan publik [1]

Dinas Kependudukan dan Catatan Sipil mengemban tugas pokok melaksanakan urusan pemerintahan di bidang administrasi kependudukan dan pencatatan sipil, meliputi aspek fasilitasi pelayanan administrasi kependudukan serta pengelolaan informasi administrasi kependudukan dan pemanfaatan data. Dalam Peraturan Pemerintah Nomor 40 Tahun 2019 tentang Pelaksanaan Undang-Undang Republik Indonesia Nomor: 24 Tahun 2013 tentang Perubahan atas Undang-Undang RI No: 23 Tahun 2006 tentang Administrasi Kependudukan pasal 18 ayat (1) dan (2) dirumuskan
[3]:

(1) Bupati/walikota menyelenggarakan urusan Administrasi Kependudukan di daerah kabupaten/kota.

(2) Dalam menyelenggarakan urusan Administrasi Kependudukan sebagaimana dimaksud pada ayat (1), bupati/walikota memiliki kewenangan meliputi:

a. koordinasi penyelenggaraan urusan Administrasi Kependudukan;

b. pembentukan Dinas Kependudukan dan Pencatatan Sipil Kabupaten/Kota;

c. pengaturan tehnis penyelenggaraan urusan Administrasi Kependudukan sesuai degan peraturan perundangundangan.

d. pelaksanaan kegiatan pelayanan masyarakkat di bidang Administrasi Kependudukan;

e. penugasan kepala desa atau yang disebut dengan nama lain untuk menyelenggarakan sebagian urusan Administrasi Kependudukan;

f. penyajian data kependudukan berskala kabupaten//kota yang berasal dari Data Kependudukan yang telah dikonsolidasikan dan dibersihkan oleh Kementerian; dan

g. koordinasi pengawasan dan penyelenggaraan urusan Administrasi Kependudukan.

Selanjutnya dalam Peraturan Pemerintah Nomor 40 Tahun 2019 dirumuskan bahwa: Dalam menyelenggarakan urusan Administrasi Kependudukan, Dinas Kependudukan dan Pencatatan Sipil Kabupaten/Kota sesuai PP No: 40 Tahun 2019 , pasal 26 melaksanakan [3]:

a. koordinasi dengan kantor kementerian yang menyelenggarakan urusan pemerintahan di bidang agama kabupaten/kota dan pengadilan agama yang berkaitan dengan pencatatan nikah, talak, cerai, dan rujuk bagi Penduduk yang beragama Islam;

b. koordinasi dengan kantor kementerian yang menyelenggarakan urusan pemerintahan di bidang agama kabupaten/kota dalam memelihara hubungan timbal balik melalui pembinaan masing-masing kepada instansi vertikal dan UPT Dinas Kependudukan dan Pencatatan Sipil Kabupaten/Kota;

c. koordinasi antarlembaga Pemerintah dan lembaga non-Pemerintah di kabupaten/kota dalam penertiban pelayanan Administrasi Kependudukan; 
d. penyusunan tata cara perencanaan, pelaksanaan, pemantauan, evaluasi, dan pengendalian urusan Administrasi Kependudukan di kabupaten/kota;

e. pengadaan blangko Dokumen Kependudukan selain blangko KTP-el, formulir, dan buku untuk pelayanan pendaftaran Penduduk dan pencatatan sipil sesuai dengan kebutuhan;

f. pengelolaan dan pelaporan penggunaan blangko Dokumen Kependudukan, formulir, dan buku untuk pelayanan pendaftaran Penduduk dan pencatatan sipil;

g. pembinaan, pembimbingan, dan supervisi terhadap pelaksanaan tugas UPT Dinas Kependudukan dan Pencatatan Sipil Kabupaten/Kota, termasuk meminta laporan pelaksanaan tugas UPT Dinas Kependudukan dan Pencatatan Sipil Kabupaten/Kota yang berkaitan dengan pelayanan Pencatatan Sipil;

h. pembinaan, pembimbingan, dan supervisi terhadap penugasan kepada desa atau yang disebut dengan nama lain;

i. pelayanan secara aktif pendaftaran peristiwa kependudukan dan pencatatan peristiwa penting;

j. penerimaan dan permintaan Data Kependudukan dari Perwakilan Republik Indonesia melalui Menteri;

k. fasilitasi penyelenggaraan urusan Administrasi Kependudukan;

1. penyelenggaraan pemanfaatan Data Kependudukan;

m. sosialisasi penyelenggaraan urusan Administrasi Kependudukan;

n. kerja sama dengan organisasi kemasyarakatan dan perguruan tinggi;

o. komunikasi, informasi, dan edukasi kepada pemangku kepentingan dan masyarakat;

p. penyajian Data Kependudukan yang akurat dan dapat dipertanggungjawabkan;

q. supervisi bersama dengan kantor kementerian yang menyelenggarakan urusan pemerintahan di bidang agama kabupaten/kota dan pengadilan agama mengenai pelaporan pencatatan nikah, talak, cerai, dan rujuk bagi Penduduk yang beragama Islam dalam rangka pembangunan basis Data Kependudukan; dan

r. pengawasan penyelenggaraan urusan Administrasi Kependudukan.

Dinas Kependudukan dan Catatan Sipil Kabupaten Bolaang Mongondow adallah satu satu organisasi atau instansi peneyelengga layanan publik yang terkait dengan tugas pokoknya yaitu layanan administrasi kependudukan dan pencatatan sipil di daerah. Eketivitas pelaksanaan tugas pokoknya dalam pelayanan publik tentunya dipengaruhi oleh berbagai faktor yang saling berhubungan dan mempengaruhinya, baik itu yang berhubungan dengan keadaan sosial, politik, ekonomi, keamanan bahkan bencana (alam dan non alam).

Awal tahun 2020 dunia dikejutkan dengan bencana non alam yaitu Virus Corona yang awalnya ditemukan di Kota Wuhan Tiongkok, kemudian dengan cepat menyebar ke seluruh penjuru dunia, termasuk Indonesia, yang kemudian oleh World Health Organization (WHO) ditetapkan sebagai Pandemic Covid-19. Penyebarannya yang begitu cepat mengakibatkan pemerintah diberbagai dunia mengambil langkah-langkah strategis untuk mencegah penyebarannya, mulai dari kebijakan Lock Down, pemabatasan sosial (social distancing), dan pembatasan jarak (physical distancing) [4].

Indonesia sendiri tidak sampai menempuh kebijakan lock down, namun menempuh kebijakan pemabatasan sosial (social distancing),dan pembatasan jarak (physical distancing), oleh karena itu pemerintah daerah diberbagai daerah mengajukan permohonan menerapkan kebijakan Pembatasan Sosial Berskala Besar (PSBB), hingga kemudian pemerintah menetapkan kebijakan tatanan kehidupan normal baru (new normal), hingga kemudian pemerintah memperkenalkan kebijakan baru yaitu Pemberlakuan Pembatasan Kegiatan Masyarakat (PPKM) di Pulau Jawa dan Bali, kemudian pemerintah pemerintah memberlakukan PPKM mikro di 7 provinsi, kemudian diiukuti oleh daerah-daerah lain. Semua kebijakan tersebut di atas, bermuara pada pembatasan berbagai kegaiatan masyarakat baik di pusat-pusat perbelanjaan, sekolah, tempat-tempat ibadah, hingga perkantoran dan tempat-tempat publik seperti tempat-tempat wisata dan sebagainya [5].

Khusus pembatasan di perkantoran, pada masa PPKM diberlakukan ketentuan 25\% work from office, dan $75 \%$ worj from home. Sementara pada PPKM mikro diberlakukan ketentuan 50\% work from office dan 50\% work from home. Berbagai pembatasan tersebut dengan sendirinya akan berdampak pada pelayanan kepada masyarakat, termasuk di dalamnya Dinas Kependudukan dan Catatan Sipil Kabupaten Bolaang Mongondow, yang dalam kegiatan berhadapan langsung dengan memberikan layanan administrasi kependudukan dan pencatatan sipil kepada masyarakat. Menghadapi situasi ini birokrasi yang langsung bersentuhan dengan pelayanan publik dituntut tanggap terhadap kebutuhan pelayanan kepada masyarakat.

Berdasarkan latar belakang permasalahan tersebut, maka peneliti mengajukan usulan penelitian dengan judul : RESPONSIVITAS PELAYANAN PUBLIK DI ERA PEMBERLAKUAN PEMBATASAN KEGIATAN MASYARAKAT (PPKM) PADA DINAS KEPENDUDUKAN DAN CATATAN SIPIL KABUPATEN BOLAANG 
MONGONDOW.

\subsection{Rumusan Masalah}

Secara
permasalahan dalam penelitian inional
dirumuskan sebagai berikut:
Bagaimanakah Responsivitas Pelayanan
Publik di Era Pemberlakuan Pembatasan
Kegiatan Masyarakat Pada Dinas
Kependudukan dan Catatan Sipil
Kabupaten Bolaang Mongondow?

\subsection{Tujuan Khusus}

Adapun tujuan penelitian ini adalah menggali, menganalisis dan menginterpretasikan Responsivitas Pelayanan Publik di Era Pemberlakuan Pembatasan Kegiatan Masyarakat Pada Dinas Kependudukan dan Catatan Sipil Kabupaten Bolaang Mongondow.

\section{Metode Penelitian}

Penelitian ini menggunakan pendekatan deskriptif kualitatif yaitu berusaha mendapatkan informasi yang selengkap mungkin, menganalisis dan menginterpretasikan tentang Responsivitas Pelayanan Publik di Era Pemberlakuan Pembatasan Kegiatan Masyarakat Pada Dinas Kependudukan dan Catatan Sipil Kabupaten Bolaang Mongondow.

\subsection{Fokus Penelitian}

Fokus utama penelitian ini yaitu Responsivitas Pelayanan Publik di Era Pemberlakuan Pembatasan Kegiatan Masyarakat Pada Dinas Kependudukan dan Catatan Sipil Kabupaten Bolaang Mongondow. Implementasi Program Penataan Sistem Informasi Administrasi Kependudukan di dalamnya terdapat kegiatankegiatan yang menunjang fasilitasi dan produksi dokumen Kependudukan dan Pencatatan Sipil, menyangkut Mekanisme atau Proses Pembuatan Dokumen KK, KTP-El, Akta Kelahiran, Akta Kematian, dan Akta Perkawinan. Fokus utama tersebut di atas dalam penelitian ini dijabarkan ke dalam dua situasi yang berbeda yaitu:

1. Kebijakan layananan administrasi kependudukan dan catatan sipil di era PPKM

2. Mekanisme layanan administrasi keppendudukan dan catatan sipil di era PPKM

a. Layanan Daring

b. Layanana Luring (Layanan di Kantor, Layanan Keliling)

3. Faktor-faktor yang mempengaruhi layanan administrasi kependudukan dan catatan sipil di era PPKM.

\subsection{Lokasi Penelitian}

Penelitian ini dilaksanakan di Dinas Kependudukan dan Catatan Sipil Kabupaten Bolaang Mongondow.

\subsection{Sumber Data}

a. Key informan sebagai informan utama dalam penelitian ini ditentukan secara sengaja (purposive sampling) adalah Kepala Dinas Kependudukan dan Catatan Sipil Kabupaten Bolaang Mongondow, sedangkan sampel selanjutnya ditentukan dengan menggunakan teknik snowball sampling.

b. Situasi dan Peristiwa Sosial yang dapat teramati selama proses penelitian berlangsung.

c. Dokumen yaitu dokumen-dokumen yang berhubungan dengan fokus penelitian.

\subsection{Teknik Pengumpulan Data}

Teknik pengumpulan data yang digunakan dalam penelitian ini adalah: a) Wawancara mendalam (indeph interview), b. Observasi, dan c. Dokumentasi [6].

\subsection{Teknik Analisis Data}

Teknik Analisis Data menurut Sugiyono analisis data adalah proses mencari dan menyusun data secara sistematis data yang diperoleh dari hasil wawancara, catatan lapangan dan dokumentasi, dengan cara mengorganisasikan data ke dalam kategori, menjabarkan ke dalam unit-unit, melakukan sintesa, menyusun ke dalam pola, memilih mana yang penting dan yang akan dipelajari, dan membuat kesimpulan sehingga mudah dipahami oleh diri sendiri maupun orang lain [7]. Teknik analasis data menggunakan model analisis interaktif dari Miles dan Huberman mengemukakan terdapat 3 langkah dalam analisis data, yaitu reduksi data, display data, dan verifikasi [8].

\subsection{Keabsahan Data}

Untuk menentukan keabsahan data dalam penelitian kualitatif harus memenuhi beberapa persyaratan atau kriteria sebagaimana dikemukakan oleh Moleong dan Nasution yang dalam pemeriksaan keabsahan data menggunakan empat kriteria yaitu: derajat kepercayaan (credibility), keteralihan (transferability), ketergantungan (dependability) dan kepastian (confirmability) [9].

\section{Hasil dan Pembahasan}

\subsection{Gambaran Umum Lokasi Penelitian}

Amandemen Keempat Undang-Undang Dasar Negara Republik Indonesia Tahun 1945 Pasal 28 B Ayat 2 menyebutkan bahwa setiap anak berhak atas kelangsungan hidup, tumbuh, dan berkembang serta berhak atas perlindungan dari kekerasan dan diskriminasi. Anak dari sisi kehidupan berbangsa dan bernegara adalah masa depan bangsa dan generasi penerus cita-cita bangsa, sehingga Negara berkewajiban memenuhi hak setiap anak atas 
kelangsungan hidup, tumbuh dan berkembang, dan mendapatkan perlidungan dari tindak kekerasan dan diskriminasi [10].

Berdasarkan Undang-undang Nomor 39 Tahun 1999 tentang Hak Azazi Manusia Pasal 52 ayat 1 menyebutkan setiap anak berhak atas perlindungan oleh orang tua, keluarga, masyarakat, dan Negara [11]. Salah satu hal penting yang melekat pada diri kita adalah Kartu Tanda Kependudukan, Akta Kelahiran, Akta kematian, dan Akta perceraian. Menurut Undang-undang Nomor 23 tahun 2006 tentang Administrasi Kependudukan bahwa "'Administrasi Kependudukan "' adalah rangkaian kegiatan penataan dan penertiban dalam penertiban dokumen dan data kependudukan melalui pendaftaran penduduk, pencatatan sipil, pengelolaan informasi, administrasi kependudukan serta pendayagunaan hasilnya untuk pelayanan publik [12].

Bahwa efisiensi dan efektivitas penyelenggaraan pemerintahan daerah perlu ditingkatkan dengan lebih memperhatikan aspekaspek hubungan antar susunan pemerintahan dan antar pemerintahan daerah, potensi dan keanekaragaman daerah, peluang dan tantangan persaingan global dengan memberikan kewenangan yang seluas-luasnya kepada daerah disertai dengan pemberian hak dan kewajiban menyelenggarakan otonomi daerah dalam kesatuan sistem penyelenggaraan pemerintah daerah. Pemerintah mempunyai tugas memberikan pelayanan yang sebaik- baiknya kepada masyarakat karena sudah menjadi peran pemerintah sebagai abdi rakyat dan abdi negara yang baik. Melalui kebijakan yang ditetapkan, pemerintah berupaya memberikan sesuatu yang maksimal dalam rangka penyelenggaraan kehidupan bernegara yang berorientasi pada kemakmuran dan keseimbangan rakyatnya.

Tugas pokok Dinas Kependudukan dan Pencatatan Sipil Kabupaten Bolaang Mongondow adalah melaksanakan sebahagian kewenangan Pemerintah Kabupaten Bolaang Mongondow dibidang kependudukan dan Pencatatan sipil. Dan fungsi Dinas Kependudukan dan pencatatan Sipil adalah:

1. Menyelenggarakan pelayanan dalam bidang Kependudukan dan Pencatatan Sipil.

2. Menyusun program Kebijakan dalam bidang kependudukan dan Pencatatan Sipil.

3. Melaksanakan pelayanan, administrasi dalam bidang Kependudukan, Akta kelahiran, kematian, perceraian, perubahan nama dan pengakuan anak.

4. Menyususn kebijakan operasional keluarga pra sejahtera

5. Melaksanakan pengawasan dan pengendalian jumlah penduduk

6. Pengelolaan administrasi umum yang meliputi ketatausahaan, kepegawaian, keuangan, perlengkapan, perecanaan, dan organisasi dinas.

7. Melaksanakan tugas-tugas yang diberikan oleh kepala Daerah sesuai dengan bidang tugasnya.

\subsection{Hasil dan Pembahasan}

Dalam Bagian ini penulis akan memaparkan hasil penelitian tentang hal yang berkaitan dengan responsivitas pelayanan di Dinas Kependudukan dan Pencatatan Sipil Kabupaten Bolaang Mongondow. Dalam mencapai kepuasan masyarakat terhadap pelayanan yang diberikan, maka diperlukan adanya resposivitas atau daya tanggap pelayanan publik Dinas Kependudukan dan Pencatatan Sipil Kabupaten Bolaang Mongondow. Responsivitas ini berkaitan dengan kemampuan untuk mengetahui dan memahami kebutuhan maupun keinginan masyarakatnya, sehingga pelayanan yang diberikan Disdukcapil dapat sesuai dengan apa yang diinginkan oleh masyarakat. Untuk melihat responsivitas pelayanan publik pada Disdukcapil Kabupaten Bolaang Mongondow, penulis menggunakan empat indikator responsivitas menurut Zeithaml, dalam Hardyansyah yaitu [13]:

3.2.1 Merespon setiap masyarakat / pemohon yang ingin mendapatkan pelayanan

Indikator ini mecakup sikap dan komunikasi yang baik dari Pegawai ketika ada masyarakat yang ingin mendapatkan pelayanan. Sikap adalah sekumpulan respon yang konsisten terhadap objek social menurut campbel dalam Notoatmodjo, Sikap yang baik yang dimaksud disini seperti keramahan, kesopanan dan keadilan Pegawai Disdukcapil Kabupaten Bolaang Mongondow kepada masyarakat Era Pemberlakuan Pembatasan Kegiatan Masyarakat (PPKM). Sikap yang baik ini merupakan langkah awal untuk menunjukkan bahwa Pegawai Disdukcapil Kabupaten Bolaang Mongondow telah siap dan mau melayani atau merespon masayarakat sehingga masyarakat dapat merasa diterima dengan baik oleh Pegawai Disdukcapil Kabupaten Bolaang Mongondow [14].

Selain sikap, komunikasi yang baik juga diperlukan pada indikator ini. Komunikasi merupakan proses dimana dua orang atau lebih melakukan pertukaran informasi antar satu sama lain [15]. Dengan komunikasi yang baik maka masyarakat akan dengan mudah memahami informasi yang disampaikan oleh Pegawai Disdukcapil Kabupaten Bolaang Mongondow. Sikap dan komunikasi Pegawai Disdukcapil Kabupaten Bolaang Mongondow ketika melayani masyarakat merupakan hal awal yang memberikan kesan pada masyarakat mengenai pelayanan Disdukcapil Kabupaten Bolaang Mongondow tersebut di Era Pemberlakuan Pembatasan Kegiatan Masyarakat (PPKM). Sikap yang baik, ramah, dan sopan dari Pegawai Disdukcapil Kabupaten Bolaang Mongondow akan membuat masyarakat merasa nyaman dan akan merasa diterima dengan baik oleh 
para Pegawai Disdukcapil Kabupaten Bolaang Mongondow.

3.2.2 Pegawai melakukan pelayanan dengan cepat

Indikator kecepatan melayani ini merupakan kesigapan Pegawai Disdukcapil Kabupaten Bolaang Mongondow dalam melayani masyarakat. Pegawai yang nelakukan pelayanan dengan cepat dapat dilihat dari kesigapannya. Kesigapan ini ditunjukkan dengan adanya Pegawai yang cekatan dan segera melayani masyarakat yang membutuhkan bantuan, serta menanggapi dengan cepat apabila ada masyarakat yang bertanya. Walaupun berada di tengah Era Pemberlakuan Pembatasan Kegiatan Masyarakat (PPKM) namun Kecepatan melayani dengan baik telah diberikan pihak Pegawai kepada masyarakat sangat cepat sehingga masyarakat merasa Pegawai Disdukcapil Kabupaten Bolaang Mongondow sigap dan tulus melayani masyarakat jika mengalami masalah dan dapat disimpulkan pelayanan dengan cepat telah diberikan oleh Pegawai Disdukcapil Kabupaten Bolaang Mongondow dibuktikan dengan tidak adanya keluhan masyarakat mengenai keterlambatan pelayanan.

3.2.3 Pegawai melakukan pelayanan dengan cermat

Pelayanan dengan cermat yaitu fokus, sungguh-sungguh dan teliti dalam memberikan pelayanan kepada masyarakat baik dalam pekerjaan maupun pembicaraan. sungguh berarti melakukan sesuatu dengan benar di Era Pemberlakuan Pembatasan Kegiatan Masyarakat (PPKM). Kecermatan dalam penyelidikan maupun pembicaraan dalam penyampaian informasi terhadap masyarakat merupakan salah satu foctor yang berdampak besar terhadap kepercayaan masyarakat. Kecermatan Pegawai Disdukcapil Kabupaten Bolaang Mongondow ini dilakukan dengan selalu memberikan pelayanan yang terbaik kepada masyarakat. Dan selalu mengingat bahwa tujuan yang ingin dicapai adalah untuk memberikan rasa aman, nyaman kepada masyarakat dan membuat masyarakat merasa puas dengan pelayanan yang diberikan.

Dapat disimpulkan mengenai indikator kecermatan dalam melayani, Disdukcapil Kabupaten Bolaang Mongondow telah melakukan pelayanan dengan cermat dan sesuai dengan apa yang diharapkan oleh masyarakat selaku penerima layanan di Disdukcapil Kabupaten Bolaang Mongondow tersebut.

4.2.4 Pegawai melakukan pelayanan dengan waktu yang tepat

Pelayanan dengan waktu yang tepat yang dimaksud disini adalah pelayanan dapat diselesaikan dalam waktu yang telah ditentukan atau tidak mengulur-ngulur waktu dalam melayani masyarakat dan kedisiplinan para Pegawai Disdukcapil Kabupaten Bolaang Mongondow dalam melayani masyarakat Era Pemberlakuan Pembatasan Kegiatan Masyarakat (PPKM). Ketepatan waktu Pegawai sangat penting, sebab jika terlambat masyarakat akan merasa kecewa terhadap pelayanan di Disdukcapil Kabupaten Bolaang Mongondow ini. Ketepatan waktu ini juga merupakan salah satu factor yang mempengaruhi kepuasan masyarakat. Ketepatan waktu sangat menentukan penilaian masyarakat mengenai baik tidaknya pelayanan yang diberikan sesuai dengan waktu yang telah ditetapkan.

\section{Kesimpulan}

Kesimpulan yang didapatkan mengenai Responsivitas Pelayanan Publik Di Era Pemberlakuan Pembatasan Kegiatan Masyarakat (PPKM) Pada Dinas Kependudukan Dan Catatan Sipil Kabupaten Bolaang Mongondow, adalah dimana Para Pegawai di Dinas Kependudukan Dan Catatan Sipil Kabupaten Bolaang Mongondow merespon setiap masyarakat / pemohon yang ingin mendapatkan pelayanan dengan prima dan totalitas walaupun masih berada di Era Pemberlakuan Pembatasan Kegiatan Masyarakat (PPKM) dengan sikap dan komunikasi yang diberikan oleh pegawai Disdukcapil yang dapat dikatakan baik sehingga masyarakat merasa nyaman. Pegawai Disdukcapil Kabupaten Bolaang Mongondow melakukan pelayanan dengan cepat kesigapan dan ketulusan. Pegawai Disdukcapil Kabupaten Bolaang Mongondow dalam melayani masyarakat dapat dilihat dari kesigapannya dalam melayani masyarakat. Kesigapan ini ditunjukkan dengan adanya Pegawai Disdukcapil Kabupaten Bolaang Mongondow yang cekatan dan segera melayani masyarakat yang membutuhkan bantuan, serta menanggapi dengan cepat apabila ada masyarakat yang ingin Mengurus keluhan ataupun permintaan pembuatan SIM, KTP ataupun KK walaupun berada di Era Pemberlakuan Pembatasan Kegiatan Masyarakat (PPKM). Pegawai Disdukcapil Kabupaten Bolaang Mongondow melakukan pelayanan dengan cermat dengan melayani masyarakat dengan fokus, bersungguh-sungguh dan teliti baik dalam pekerjaan maupun pembicaraan. Pegawai Disdukcapil Kabupaten Bolaang Mongondow melakukan pelayanan dengan waktu yang tepat dengan ketepatan waktu melayani yang dapat diselesaikan dalam waktu yang telah ditentukan dan kedisiplinan pegawai Disdukcapil Kabupaten Bolaang Mongondow, serta tidak tidak terjadi kesalahan dalam melayani

\section{Referensi}

[1] P. Publik and P. R. Indonesia, "UU Nomor 25 Tahun 2009 Tentang"Pelayanan Publik"," UU Nomor 25 Tahun 2009 Tentang"Pelayanan Publik", 2009.

[2] T. Miftah, Ilmu Administrasi Publik Kontemporer,. Jakarta: Kencana, 2012.

[3] Dalam Peraturan Pemerintah Nomor 40 Tahun 2019 tentang Pelaksanaan Undang- 
Undang Republik Indonesia Nomor: 24

Tahun 2013 tentang Perubahan atas Undang-Undang RI No: 23 Tahun 2006 tentang Administrasi Kependudukan. .

[4] U. T. Wijayanti, "Pandemi Covid-19," Analisis Faktor Penyebab Perceraioan Pada Masa Pandemi Covid-19 Di Kabupaten Banyumas, vol. 14. 2021.

[5] U. Napitu, Corry, and M. K. D. Matondang, "Sosialisasi pembatasan pelaksanaan kegiatan masyarakat (PPKM) mikro di kelurahan bah Kapul," Community Dev. J., vol. 2, no. 2, 2021.

[6] A. Dilapanga, "Pengembangan Organisasi," vol. 1, no. 2, pp. 6-11, 2016.

[7] Sugiyono, "Memahami Penelitian Kualitatif," Bandung Alf., 2016.

[8] M. Miles, M. B. \& Huberman, Analisis Data Kualitatif. Penerbit Universitas Indonesia: Penerbit Universitas Indonesia, 1992.

[9] L. J. Moleong, Metodologi Penelitian Kualitatif (Edisi Revisi). 2017.

[10] UUD 45, "Undang-undang Dasar RI Tahun 1945," Dep. Kesehat. RI, 1945.

[11] Presiden Republik Indonesia, "UndangUndang No . 39 Tahun 1999 Tentang : Hak Asasi Manusia," Undang. Republik Indones. Nomor 39 Thn 1999 tentang Hak Asasi Mns., no. 39, 1999.

[12] "Undang-Undang Nomor 23 Tahun 2006 tentang Administrasi Kependudukan.” 2006.

[13] Hardiansyah, Kualitas Pelayanan Publik. 2011.

[14] Notoatmodjo, "Notoatmodjo," Pengetah. Sikap dan Perilaku, vol. 2, no. 1, 2014.

[15] J. A. Sonquist, “ Communication Networks: Toward a New Paradigm for Research. Everett M. Rogers , D. Lawrence Kincaid ," Am. J. Sociol., vol. 89, no. 4, 1984. 